\title{
The Learning Strategy of Islamic Education at Primary School in Implantation of Islamic Thought Values
}

\author{
*Dalmi Iskandar Sultani1 ${ }^{1}$ Cita Ayni Putri Silalahi' ${ }^{2}$, Rahmadi Ali ${ }^{3}$
}

1,2,3 Universitas Muslim Nusantara Al Washliyah Medan, Indonesia

\section{A R T I C L E I N F O}

Article history:

25 December 2020

Received in revised form

01 January 2021

Accepted 25 January 2021

Available online 03

Pebruari 2021

Kata Kunci:

Pendidikan Agama Islam,

Strategi Pembelajaran

Keywords:

Islamic Religious Education,

Learning Strategies

\begin{abstract}
A B S T R A K
Penerapan strategi pembelajaran yang belum mampu membuat siswa bersemangat dalam mengikuti kegiatan pembelajaran, karena kurangnya penerapan strategi pembelajaran yang kreatif dan inovatif. Penelitian ini bertujuan untuk menganalisis strategi yang diterapkan oleh guru agama pada siswa, untuk mengetahui efektivitas strategi yang terlibat dalam penanaman nilai-nilai pemikiran Islam di SD. Jenis penelitian ini adalah penelitian deskriptif. Subjek penelitian ini adalah mnganalisis strategi pendidikan islam. Pengumpulan data dilakukan dengan wawancara, dengan menggunakan istrumen berupa pedoman wawancara. Teknik analisis data pada penelitian ini manggunakan teknik analisis data deskriptif kualitatif. Hasil penelitian menunjukkan bahwa strategi guru agama Islam dalam menanamkan nilai-nilai pemikiran Islam pada siswa dengan mengimplementasikan kurikulum K13 dengan metode tongkat bicara dan bola salju untuk menciptakan
\end{abstract} pembelajaran yang efektif agar mencapai tujuan pembelajaran dengan merencanakan pembuatan program tahunan, program semester, silabus pembelajaran, RPP, dan evaluasi pembelajaran. Implikasi penelitian ini adalah meningkatkan minat belajar siswa dengan mengajak siswa untuk bersemangat belajar, menciptakan kreativitas siswa, berbagi, dan berani menyampaikan gagasanr.

\begin{abstract}
A B S T R A C T
The implementation of learning strategies that have not been able to make students enthusiastic in participating in learning activities, is due to the lack of application of creative and innovative learning strategies. This study aims to analyze the strategies applied by religious teachers to students, to determine the effectiveness of the strategies involved in cultivating Islamic thought values at Elementary School. This type of research is descriptive research. The subject of this research is to analyze Islamic education strategies. Data collection was carried out by interview, using instruments in the form of interview guides. The data analysis technique in this study uses descriptive qualitative data analysis techniques. The results showed that the strategy of Islamic religious teachers in instilling the values of Islamic thought in students by implementing the K13 curriculum with the talking stick method and snowballing to create effective learning in order to achieve learning objectives by planning making annual programs, semester programs, learning syllabus, lesson plans, and learning evaluation. The implication of this research is to increase students' interest in learning by inviting students to be enthusiastic about learning, creating student creativity, sharing, and having the courage to convey ideas.
\end{abstract}

\section{Introduction}

Islamic religious education is one of the means of cultivating (enculturation) society because Islamic teachings do not only discuss one aspect but include all aspects of life, both worship, shari'ah, mu'amalah and other aspects so that with Islamic religious education the pattern of life and behavior society becomes directed according to the teachings and noble values. Islamic religious education in elementary schools is more emphasized on the practice and habituation of religious activities supported by simple knowledge and understanding of the relevant religious teachings to be applied in everyday life. (Desy, 2015; Nuryana \& Sahrir, 2020; Timutiasari et al., 2016). 
Teaching and learning success is how to apply a learning strategy, how good the strategy is, then how much is the result. Students are expected to be comfortable and happy in the learning process so that the values of Islamic thought are well manifested (Khafidin, 2014; Khodijah, 2018; Sofyani et al., 2012). If not, the wrong strategy results in negative things, students feel bored, lazy, and bored. Finally, the values of Islamic thought are not accepted and lead to bad behavior and attitudes. Learning strategy is defined as planning which contains activities and designs to achieve educational goals. To achieve a good learning process, a good learning strategy is needed. Because it has a role, the school helps students to live more meaningfully. Observers assess the need to emphasize and instill the values of Islamic thought in elementary school students so that children are expected to be able to protect themselves and avoid disgraceful behavior. Islamic education is not only a cognitive realm but is also practiced in the daily life of children (Purwanti, 2017; Syafri, 2016; Syam, 2019). Children who have a good understanding and knowledge of the values of Islamic thought have been engraved in faith and are expected to have a useful life.

Based on the results of observations made to find out how Islamic education learning strategies in Islamic education learning at Public Elementary School No. 105321, Tumpatan Nibung Village, Batang Kuis District, Deli Serdang Regency. The lack of implementing innovative learning strategies makes students less enthusiastic in participating in learning activities. Teachers of Islamic Religious Education are expected to be able to implement learning strategies in learning that are oriented towards the implementation of daily life. Islamic education teachers are very important to generate good enthusiasm for student learning and instill a complete understanding and knowledge of Islamic values (Mudlofir, 2013; Mukaromah, 2018; Oviana, 2017). Therefore, students reflect good morals and worship of knits in everyday life, as well as avoidance behavior.

Elementary school-age, unstable, have a high curiosity about what is seen in the environment where he does what he sees whether it is true or not. To be precise, this age should learn and play. Then move from childhood to early adolescence. Curiosity is high in childhood increases in early adolescence. The process of acquiring an identity requires a transition to mature thinking and developing good social interaction skills. Unstable conditions must receive motivation and guidance, as well as good education and teaching, especially Islamic education (Mukaromah, 2018; Purwanti, 2017; Ramadoni et al., 2016). To instill the values of Islamic thought in students, parents and teachers are required to guide children to things that are useful since elementary school age.

Learning in educational institutions must uphold values and passion with strategies. The teacher's efforts to establish a comfortable learning climate are imperative. That conducive learning has a strategy to make students excited and easily absorb the lessons. One of the efforts made by Islamic Religious Education teachers is to implement learning strategies to increase enthusiasm and interest in learning. The continuous application of learning strategies raises the enthusiasm and excitement of the students. Therefore, the material of Islamic education is easier for students to understand. The learning strategy itself is a method applied by the teacher to select learning activities to be used in the learning process (Burhanah Farida, 2015; Hartana et al., 2016; Retnowati \& Aqiila, 2017).

The learning strategy is to organize the learning context, deliver learning and manage learning activities by using various learning resources by the teacher, such as teaching aids, textbooks, and index cards in carrying out the teaching and learning process in the classroom so that learning runs effectively and efficiently (Adibatin, 2016; Arifin et al., 2018; Musaffak, 2014). Learning strategies can be interpreted as a complete approach in the learning system in the form of general guidelines and activity frameworks to achieve general learning objectives which describe systematic procedures to assist student learning efforts, organize learning experiences, manage and plan material to achieve learning objectives (Ramadhanti, 2015; Rizal \& Munip, 2017; Sucipto, 2017). So, learning strategies can be collected as a process or way of carrying out learning to support student learning activities that compile, manage, and plan material so that the learning process is effective and efficient to achieve planned and implemented learning objectives.

The learning strategy consists of several types that must be implemented by the teacher, namely: (1) expository learning strategies; (2) inquiry learning strategies; (3) problem-based learning strategies; (4) improving thinking skills learning strategies; (5) cooperative learning strategies; (6) contextual learning strategies; (7) affective learning strategies (Adibatin, 2016; Fatimah \& Kartikasari, 2018; Hapsari et al., 2019). This learning strategy can be applied, one of which is in Islamic education.

Islamic education is conscious guidance or leader by the teacher for the physical and spiritual development of students towards the formation of the main personality, namely insan kamil (Mukaromah, 2018; Oviana, 2017; Ramadoni et al., 2016). Islamic education can be interpreted to instill good morals in young people in their infancy and to extinguish them with water instructions and suggestions so that morals come in the ability or penetrate the soul, the result is in the form of virtue and love to work for the 
benefit of the country (Desy, 2015; Khafidin, 2014; Khodijah, 2018). Based on this definition, it can be concluded that Islamic education is a system of coaching students' lives based on the Qur'an and Hadith. Besides, Islamic education enhances mental and moral forms of charity for oneself or others.

The sciences that form the basis of Islamic education include: (1) The Qur'an, which is the word of Allah, was massaged on the Prophet Muhammad in Arabic clearly, to explain a way of life that is beneficial to mankind in this world and the hereafter; (2) sunnah or hadith, which are the Prophet's behavior and speech exemplified in preaching or preaching Islam and hadith is the main source of education in the implementation of Islamic education which is used as a theoretical and practical reference; (3) Ijtihad, which supports educational media as the main media for developing social life institutions (Khodijah, 2018; Mudlofir, 2013; Oviana, 2017).

To get the right information about the learning strategies of Islamic education at Public Elementary School Number 105.321 Tumpatan Nibung, Batang Kuis Village, Deli Serdang District, in the implementation of Islamic thought values, observers hope that it contributes to research ideas to improve Islamic education learning based on learning strategies and life experience. One of the teacher's efforts to improve learning is to create and manage strategies. A good learning strategy will increase good results. The use of learning strategies will make it easier for teachers to carry out the teaching and learning process. A good and well-executed strategy makes it easier for teachers to achieve planned goals (Burhanah Farida, 2015; Hartana et al., 2016; Purba, 2018). A good learning strategy that is applied continuously is structured and directed to make students happy and enthusiastic in learning so that Islamic education material is well received.

This research is supported by several studies, namely: (1) research conducted by (Maryance, 2016), who obtained the results of the research that learning PAI subjects at the Bina Husada College of Health Sciences in Palembang which prioritized religious sciences and were content-oriented tended to apply a material-centered education model; (2) research conducted by (Akmal \& Susanti, 2019), who obtained the research results that the impact of the use of rewards in learning Islamic religious education is influenced by several factors such as strong teacher and school encouragement in motivating students, as well as teacher consistency; (3) research conducted by (Mudlofir, 2013), who obtained the results of research that the character in Islamic education must be actualized in the education system so that virtuous human beings are formed.

The purpose of this study was to determine the Islamic education learning strategies implemented in Islamic education learning at SDN 105321, Tumpatan Nibung Village, Batang Kuis District, Deli Serdang Regency and to determine the extent of the teacher's efforts to motivate students to be more active and enthusiastic in the learning process.

\section{Method}

The research was conducted through field observations, descriptive qualitative. Procedure research produces descriptive data on those written or spoken speech and observed behaviors. The research conducted is describing situations and phenomena (Akmal \& Susanti, 2019; Maryance, 2016; Roqib, 2015). Observing how Islamic education learning strategies are suitable for making qualitative observations. The data collection plan will be explained.

The research was conducted at the State Elementary School No. 105321, Tumpatan Nibung Village, Batang Kuis District, Deli Serdang Regency. This research involved Islamic education teachers at SDN No 105321, Tumpatan Nibun Village, Batang Kuis District, Deli Serdang Regency.

The method of collecting data for analysis is the process of systematically searching and organizing the interview data obtained, field notes, and documentation by organizing the data into categories, describing them into units, synthesizing them, arranging them into patterns, selecting what is important and what is important. learned is, and makes conclusions in order to be understood.

The data analysis method is to interpret the constructed and selected data. So the data analysis used is qualitative data with four stages, namely: (1) data collection; (2) data reduction; (3) presentation of data; (4) verification (Khodijah, 2018; Maryance, 2016; Mudlofir, 2013).

\section{Result and Discussion}

The teaching and learning process is carried out by greeting and asking every day how the student is doing. Have the students completed their homework? Then repeat the question of the previous lesson, after that give a brief note about the lesson that will be studied using the method of sorting the letters of the Qur'an. After the teaching and learning process is complete, the teacher provides 
reinforcement to the lesson and conveys the important messages of the lesson, then invites students to pray after the class is over.

The applied Islamic education curriculum is KTSP and K13. For classes I, II, IV, and V using the K13 curriculum. Whereas for class III, class VI still uses KTSP. Class I and IV use the K13 curriculum from 2018-2019 and classes II and V use the 2019-2020 curriculum. So, only classes III and VI still use KTSP.

The method of Islamic education often uses the talking stick method and throwing snowballs. The talking stick learning strategy uses the help of a stick. Who holds the stick must answer the teacher's questions after students have studied the subject matter, while the snowball throwing game explores the leadership potential of students in groups and understands the skills of making and answering questions combined with the imaginative play of forming and throwing snowballs.

The strategy with the talking stick and snowball learning model is to make students more enthusiastic and active to learn and understand the material more easily. Also, the method is appropriate and appropriate to be applied in the learning process in elementary schools. The application of this strategy can be applied to assist teachers in explaining Islamic education material in elementary schools.

Islamic education materials in elementary schools include (1) materials for first grade such as learning the Koran, prayer, and praiseworthy behavior; (2) materials for the second grade, such as studying the Qur'an, compassion, praying let's live in peace; (3) materials for third grade such as convenience with good behavior, learning Al Kautsar Surah, Allah who is all-knowing and all-hearing, Dzikir and Prayer after Prayer, stories of Prophet Ibrahim and Ismail; (4) materials for fourth grades, such as learning Al Fiil Surah, having faith in the Angel of Allah, behaving properly, praying, the story of Wali Songo (5) material for fifth grades such as knowing the Apostle or Rasul of Allah, living a simple and sincere life, the greatness of Tarawih and Tadarus, Luqman's exemplary story; (6) materials for fifth grade such as helping each other, receiving Qodo and Qadar, enjoyment of praiseworthy behavior, imitating the Prophets and Ashabul Kahf.

The form of activities in Islamic education learning is to increase willingness by inviting students to be enthusiastic about learning and doing each task happily. To change interest in learning, students have a high willingness and persistence to learn. Students are considered to be invited, guided, and cared for without paying attention to the differences between students and others. When the group assignment was given, all students were very enthusiastic about appearing and came forward to tell and present the results of the group work to all students in the class without feeling ashamed, afraid, and mistrustful.

The learning pattern applied in Islamic education learning is to take advantage of the instructional media, which is used by various types of teachers from available and easy to obtain media. So that students get various information from the media as a learning resource. The learning patterns include question and answer discussions, stories, demonstrations, assignments and recitation, skills training, problem-solving, talking sticks, and throwing snowballs.

The Islamic education preparation program is assumed to be an activity design for a period or year, starting with the creation of an annual program, semester program, learning syllabus, and lesson plans. The time allocation is four hours a week for classes using the K13 curriculum and three hours a week for classes using the KTSP curriculum, each of which takes 35 minutes. Especially the K13 curriculum, four hours a week divided by two meetings a week. Also, it is necessary to carry out learning evaluation activities to determine the level of student understanding of the material given.

The evaluation of Islamic education learning consists of four strategies, namely: (1) learning evaluation planning is prepared and carried out as well as possible by Islamic Religion teachers to obtain results by the wishes of the teacher and to ensure the level of understanding of each student of the lessons being taught; (2) application to obtain appropriate results, the implementation of evaluation includes three types including oral tests, written tests, and essays; (3) assessment after the evaluation is complete, the teacher gives a score to each student to ensure the progress of learning; (4) follow-up is carried out if there are students who have recently understood and understood about evaluation exams to obtain lower scores. So the Islamic Religious Education teacher invited and guided him again, then he did a repeat evaluation until each student got the best score.

The evaluation system performs the continuous evaluation. The evaluation aims to determine the achievement, progress, and success of students through the learning process and to measure the success rate of the learning program. Evaluations can be in the form of oral or written tests, observation sheets, interview guides, homework, etc. Evaluation can be done by the teacher at any time; before, during, and after learning activities.

One of the evaluation processes in the 2013 curriculum is class evaluation. So, a continuous evaluation system. Data were collected and analyzed using evaluation procedures and tools according to the indicators to be achieved. The results obtained are compared with previous learning outcomes to measure the progress of each student. Class evaluation is carried out by the teacher to determine the 
achievement of student learning outcomes, learning difficulties, and to provide feedback to improve the learning process.

The teacher's approach to adjusting learning evaluation is scientific. In the 2013 curriculum, it is stated that the learning process uses a scientific approach including attitudes, knowledge, and skills. The evaluation approach includes observing, asking, reasoning, meeting, or communicating and covering up.

The observing activity was made by groups of students, then the teacher played a video about thaharah or ablution, after which asked each group to watch the video. Here the teacher trains students to see, hear and read. Then in the questioning activity, the teacher asks students about the rukun, sunnah, and procedures for ablution, after which the students watch the video. Then in response to the teacher, students have the opportunity to ask questions about ablution or other Islamic material, such as names of prophets, names of angels, pillars of faith, and Islam. The goal is to foster student curiosity. After watching the video, each group was asked and guided to make learning media for ablution using paper according to the group's creativity. The goal is to provoke and arouse students' reasoning to be creative according to their abilities.

The next stage, representatives of each group are asked to appear in front of the class to communicate or convey the learning results and conclude in the learning media about ablution to all students. The goal is to create student creativity, share, and dare to convey ideas. In the closing activity, the teacher reflects to measure student achievement and success by giving individual and group assignments. The aim is to ensure student achievement in teaching students that everything ends there is a meeting there is ago and there is a beginning there is an end and to create an impression of hospitality that is both in attitude and fairness.

The learning strategy is to organize the learning context, deliver learning and manage learning activities by using various learning resources by the teacher, such as teaching aids, textbooks, and index cards in carrying out the teaching and learning process in the classroom so that learning runs effectively and efficiently (Adibatin, 2016a; Arifin et al., 2018; Musaffak, 2014). Learning strategies can be interpreted as a complete approach in the learning system in the form of general guidelines and activity frameworks to achieve general learning objectives which describe systematic procedures to assist student learning efforts, organize learning experiences, manage and plan material to achieve learning objectives (Ramadhanti, 2015; Rizal \& Munip, 2017; Sucipto, 2017). So, learning strategies can be collected as a process or way of carrying out learning to support student learning activities that compile, manage, and plan material so that the learning process is effective and efficient to achieve planned and implemented learning objectives.

The learning strategy consists of several types that must be implemented by the teacher, namely: (1) expository learning strategies; (2) inquiry learning strategies; (3) problem-based learning strategies; (4) improving thinking skills learning strategies; (5) cooperative learning strategies; (6) contextual learning strategies; (7) affective learning strategies (Adibatin, 2016b; Fatimah \& Kartikasari, 2018; Hapsari et al., 2019). This learning strategy can be applied, one of which is in Islamic education.

Islamic education is conscious guidance or leader by the teacher for the physical and spiritual development of students towards the formation of the main personality, namely human kamil (Mukaromah, 2018; Oviana, 2017; Ramadoni et al., 2016). Islamic education can be interpreted to instill good morals in young people in their infancy and to extinguish them with water instructions and suggestions so that morals come in the ability or penetrate the soul, the result is in the form of virtue and love to work for the benefit of the country (Desy, 2015; Khafidin, 2014; Khodijah, 2018). Based on this definition, it can be concluded that Islamic education is a system of coaching students' lives based on the Qur'an and Hadith. Also, Islamic education enhances mental and moral forms of charity for oneself or others.

This research is supported by several studies, namely: (1) research conducted by (Maryance, 2016), who obtained the results of the research that learning PAI subjects at the Bina Husada College of Health Sciences in Palembang which prioritized religious sciences and were content-oriented tended to apply a material-centered education model; (2) research conducted by (Akmal \& Susanti, 2019), who obtained the research results that the impact of the use of rewards in learning Islamic religious education is influenced by several factors such as strong teacher and school encouragement in motivating students, as well as teacher consistency; (3) research conducted by (Mudlofir, 2013), who obtained the results of research that the character in Islamic education must be actualized in the education system so that virtuous human beings are formed.

The implication of this research is to increase students' interest in learning by inviting students to be enthusiastic about learning, creating student creativity, sharing, and having the courage to convey ideas. 


\section{Conclusion}

Based on the results and discussion, it can be concluded that implementing the K13 curriculum with the talking stick and snowball method is to create effective learning to achieve learning objectives by planning the making of an annual program, semester program, learning syllabus, and lesson plans. Also, evaluation can be carried out to determine weaknesses and strengths in the implementation of learning and can be corrected by finding solutions. Therefore, a learning strategy with continuous evaluation is needed.

\section{References}

Adibatin, A. (2016a). Pendidikan Karakter Bangsa Berbasis Strategi Pembelajaran Pakem Melalui Permainan Cincin Di Jempol Tangan (Karya Inovasi Pembelajaran Sekolah Dasar). Scholaria: Jurnal Pendidikan Dan Kebudayaan, 6(1), 1-18. https://doi.org/10.24246/j.scholaria.2016.v6.i1.p1-18

Adibatin, A. (2016b). Pendidikan Karakter Bangsa Berbasis Strategi Pembelajaran Pakem Melalui Permainan Cincin Di Jempol Tangan (Karya Inovasi Pembelajaran Sekolah Dasar). Scholaria: Jurnal Pendidikan Dan Kebudayaan, 6(1), 1-18. https://doi.org/10.24246/j.scholaria.2016.v6.i1.p1-18

Akmal, S., \& Susanti, E. (2019). Analisis Dampak Penggunaan Reward Dalam Pembelajaran Pendidikan Agama Islam Di SMA Muhammadiyah Aceh Singkil. Jurnal Ilmiah Didaktika: Media Ilmiah Pendidikan Dan Pengajaran, 19(2), 159-177. https://doi.org/10.22373/jid.v19i2.5031

Arifin, R. B. M., Teh, K. S. Bin, Muhamad, N., \& Amrullah. (2018). Pemikiran Ibnu Khaldun dalam Strategi Pelaksanaan Iklim Dini Di Sekolah. Pedagogia: Jurnal Pendidikan, 7(2), 137-144. https://doi.org/10.21070/pedagogia.v6i1

Burhanah Farida. (2015). Penggunaan Strategi Pembelajaran Inkuiri Untuk Meningkatkan Hasil Belajar IPA Siswa Kelas IV Di SD N 4 Tanggung Kecamatan Tanggungharjo Kabupaten Grobogan. Jurnal Ilmiah Pendidikan Dasar, 2(1), 43-64. https://doi.org/10.30659/pendas.2.1.64-72

Desy, D. (2015). Pola Asuh Orang Tua Tunggal Dalam Mendidik Agama (Islam) (Studi Kasus Di Desa Rejosari Kecamatan Kalikajar Kabupaten Wonosobo). Jurnal Pendidikan Agama Islam, 12(1), 7594. https://doi.org/10.14421/jpai.2015.121-06

Fatimah, F., \& Kartikasari, R. D. (2018). Strategi Belajar dan Pembelajaran dalam Meningkatkan Keterampilan Bahasa. Pena Literasi, 1(2), 108-113. https://doi.org/10.24853/pl.1.2.108-113

Hapsari, E. E., Sumantri, M. S., \& Astra, I. M. (2019). Strategi Guru Meningkatkan Hasil Belajar Menggunakan Pendekatan Saintifik Di Sekolah Dasar. Jurnal Basicedu, 3(2), 850-860. https://doi.org/10.31004/basicedu.v4i4.445

Hartana, A., Setyosari, P., \& Kuswandi, D. (2016). Penerapan Strategi Pembelajaran Paradigma Pedagogi Ignatian ( Reflektif) Terhadap Peningkatan Hasil Belajar Dan Motivasi Berprestasi Belajar Ilmu Pengetahuan Alam ( IPA ) Siswa Kelas V. Teori, Penelitian, Dan Pengembangan, 1(4), 765-779. https://doi.org/10.17977/jp.v1i4.6555

Khafidin, Z. (2014). Analisis Validitas Dan Reliabilitas Tes Mata Pelajaran Pendidikan Agama Islam Tingkat SMA. Edukasia: Jurnal Penelitian Pendidikan Islam, 9(2). https://doi.org/10.21043/edukasia.v9i2.775

Khodijah, N. (2018). Pendidikan Karakter Dalam Kultur Islam Melayu (Studi Terhadap Pola Asuh Orang Tua, Faktor-Faktor Yang Mempengaruhinya, Dan Pengaruhnya Terhadap Religiusitas Remaja Pada Suku Melayu Palembang). Tadrib: Jurnal Pendidikan Agama Islam, 4(1), 21-39. https://doi.org/10.19109/tadrib.v4i1.1949

Maryance. (2016). Analisis Pembelajaran Mata Kuliah Pendidikan Agama Islam di Sekolah Tinggi Ilmu Kesehatan Bina Husada Palembang. Ta'dib: Jurnal Pendidikan Islam, 5(2), 71-76. https://doi.org/10.29313/tjpi.v5i1.1987

Mudlofir, A. (2013). Pendidikan Karakter: Konsep dan Aktualisasinya dalam Sistem Pendidikan Islam. Nadwa, 7(2), 229-363. https://doi.org/10.21580/nw.2013.7.2.560

Mukaromah, S. M. (2018). Pengembangan Modul IPA Braille Berbasis Integrasi Islam dan Sains. INKLUSI: 
Journal of Disability Studies, 5(2), 195-216. https://doi.org/10.14421/ijds.050203

Musaffak. (2014). Peningkatan Kemampuan Menulis Makalah Mahasiswa Pengambil Matakuliah Bahasa Indonesia Keilmuan Jurusan Pendidikan Bahasa Inggris FKIP UMM Semester II 2012 Dengan Strategi Peta Pikiran. Jurnal Pendidikan Humaniora, 1(4). https://doi.org/10.17977/jph.v1i4.4145

Nuryana, N., \& Sahrir, D. C. (2020). Pelatihan Kurikulum 2013 Edisi Revisi 2018 bagi Guru di Yayasan Pendidikan Islam Al-Maunah. Jurnal Pengabdian Pada Masyarakat, 5(1), 1 - 10. https://doi.org/10.30653/002.202051.259

Oviana, W. (2017). Pengembangan Sikap Spiritual Islami Dan Ketrampilan Proses Sains Siswa Dalam Pembelajaran Ipa Di Madrasah Ibtidaiyah Krueng Sabee Aceh Jaya. Jurnal Ilmiah Didaktika, 17(1), 101-117. https://doi.org/10.22373/jid.v17i1.1588

Purba, N. (2018). Perbaikan Hasil Belajar Siswa Melalui Penerapan Strategi Pembelajaran Berbasis Masalah Pada Kompetensi Dasar Perubahan Sifat Benda Pelajaran IPA Di Kelas IV SD Negeri 060829. Elementary School Journal, 8(1), 74-89. https://doi.org/10.24114/esjpgsd.v8i1.10351

Purwanti, K. L. (2017). Penerapan Literasi Lintas Kurikulum Matematika Dalam Pembelajaran Kelas Tinggi Di MIT Nurul Islam Ngaliyan Semarang Tahun 2016. Phenomenon : Jurnal Pendidikan MIPA, 7(1), 79. https://doi.org/10.21580/phen.2017.7.1.1497

Ramadhanti, D. (2015). Strategi Penggunaan Kosakata Dan Tata Bahasa Dalam Berita Harian Umum Independen Singgalang. Jurnal Gramatika: Jurnal Penelitian Bahasa Dan Sastra Indonesia, 1(1), 89-99. https://doi.org/10.22202/jg.2015.v1i1.1160

Ramadoni, W., Kusmintardjo, \& Arifin, I. (2016). Kepemimpinan Kepala Sekolah Dalam Upaya Peningkatan Kinerja Guru (Studi Multi Kasus Di Paud Islam Sabilillah Dan SDN Tanjungsari 1 Kabupaten Sidoarjo). Jurnal Pendidikan: Teori, Penelitian, DanPengembangan, 1(8), 1500-1504. https://doi.org/10.17977/jp.v1i8.6620

Retnowati, E., \& Aqiila, A. (2017). Efektivitas Strategi Pengelompokan Berpasangan Dalam Pembelajaran Matematika Model Core. Jurnal Cakrawala Pendidikan, 36(1), 13-23. https://doi.org/10.21831/cp.v35i1.12628

Rizal, S., \& Munip, A. (2017). Strategi Guru Kelas dalam Menumbuhkan Nilai-Nilai Karakter Pada Siswa SD/MI. Al Ibtida: Jurnal Pendidikan Guru MI, 4(1), 45. https://doi.org/10.24235/al.ibtida.snj.v4i1.1462

Roqib, M. (2015). Pengembangan Strategi Pembelajaran dalam Perspektif Pendidikan Islam. Insania: Jurnal Pemikiran Alternatif Kependidikan, 14(1), 19-33. https://doi.org/10.24090/insania.v14i1.316

Sofyani, H., Ulum, I., Syam, D., \& L, S. W. (2012). Islamic Social Reporting Index Sebagai Model Pengukuran Kinerja Sosial Perbankan Syariah (Studi Komparasi Indonesia Dan Malaysia). Jurnal Dinamika Akuntansi, 4(1). https://doi.org/10.15294/jda.v4i1.1958

Sucipto, S. (2017). Pengembangan Ketrampilan Berpikir Tingkat Tinggi Dengan Using Pengembangan Strategi Model Metakognitif Pembelajaran Problem Based Learning. Jurnal Pendidikan (Teori Dan Praktik), 2(1), 63-71. https://doi.org/10.26740/jp.v2n1.p77.

Syafri, Z. (2016). Analisis Evaluasi Pembelajaran Pendidikan Agama Islam Di Sma Negeri 1 Rambatan, Tanah Datar. Al-Fikrah: Jurnal Manajemen Pendidikan, 4(2), 187-197. https://doi.org/10.31958/jaf.v4i2.420

Syam, A. R. (2019). Guru dan Pengembangan Kurikulum Pendidikan Agama Islam di Era Revolusi Industri 4.0. Tadris: Jurnal Pendidikan Islam, 14(1), 1-18. https://doi.org/10.19105/tjpi.v14i1.2147

Timutiasari, B., Al-Muhdhar, M. H. I., \& Suhadi. (2016). Pembelajaran berbasis Projek Berbantuan Modul Program KRPL untuk Mengembangkan Sikap Peduli Lingkungan dan Keterampilan Proses Sains Siswa SD Islam Moh. Hatta Malang. Jurnal Pendidikan: Teori, Penelitian, Dan Pengembangan, 1(6), 1185-1190. https://doi.org/10.17977/jp.v1i6.6472 